\title{
HUBUNGAN ANTARA KECEMASAN MATEMATIKA DAN SELF-EFFICACY DENGAN HASIL BELAJAR MATEMATIKA SISWA SMA X KOTA PALANGKA RAYA
}

\author{
Wagetama. I. Disai' ${ }^{1}$, Agoes Dariyo², Debora Basaria ${ }^{3}$ \\ Fakultas Psikologi, Universitas Tarumanagara Jakarta \\ Email:wagetama95@gmail.com
}

\begin{abstract}
ABSTRAK
Richardson dan Suinn (dalam Mahmood \& Khatoon, 2011) mengatakan bahwa kecemasan Matematika adalah perasaan tegang dan cemas yang menggangu dan bisa menghambat kemampuan mental aritmetika dalam kehidupan sehari-hari. Bandura (dalam Feist \& Feist, 2013) mendefinisikan selfefficacy sebagai keyakinan diri seseorang pada kemampuannya untuk melakukan kontrol terhadap peristiwa yang sedang mereka hadapi. Tujuan dari penelitian ini untuk mengetahui hubungan antara kecemasan Matematika dan self-efficacy dengan hasil belajar Matematika siswa SMA X di Kota Palangka Raya, Kalimantan Tengah. Peneliti menyertakan 467 siswa yang berasal dari kelas X, XI, dan XII menggunakan teknik purposive sampling. Pengambilan data dengan menggunakan kuesioner kecemasan Matematika, dan kuesioner self-efficacy serta data hasil belajar Matematika berdasarkan nilai rapot siswa. Analisis data dalam penelitian ini yaitu menggunakan teknik spearman correlation. Hasil penelitian menunjukkan terdapat hubungan signifikan negatif antara kecemasan Matematika dan hasil belajar Matematika siswa SMA ( $r=-0,196$ dan $p=0,000<0,05)$. Hasil penelitian ini juga menunjukkan bahwa terdapat hubungan signifikan positif antara self-efficacy dengan hasil belajar Matematika siswa SMA $(r=0,210$ dan $p=0,000<0,05)$.
\end{abstract}

Kata Kunci: Hasil Belajar Matematika, Kecemasan Matematika, Self-Efficacy

\section{PENDAHULUAN}

Pendidikan formal di Indonesia mulai dari jenjang TK, SD, SMP, sampai dengan SMA memiliki kurikulum yang telah disusun sesuai dengan kebutuhan peserta didik dan lingkungannya (Peraturan Menteri Pendidikan Nasional, 2006). Salah satu pelajaran yang ada pada kurikulum setiap jenjang pendidikan di Indonesia adalah berhitung atau Matematika. Pada tahun 2014 tingkat kelulusan Ujian Nasional (UN) jenjang SMA mencapai 99.52\%. Dari total peserta UN SMA yang berjumlah 1.632 .757 siswa, sebanyak $7.811(0.48 \%)$ dinyatakan tidak lulus UN, jumlah ini menurun dibandingkan dengan tahun sebelumnya (Kementerian Pendidikan dan Kebudayaan, 2014).

Bagi kebanyakan pelajar di Indonesia, Matematika merupakan pelajaran yang sangat sulit. Hal ini terbukti dari survei yang dilakukan oleh sebuah organisasi di bawah naungan Organization Economic Cooperation and Development (OECD) yang bernama Programme For International Student Assessment (PISA). PISA melakukan survei terhadap 65 negara di dunia tahun 2012. Hasil survei itu mengatakan bahwa kemampuan Matematika siswa-siswi di Indonesia menduduki peringkat 64 dari 65 negara dengan skor 375 dari skor paling tinggi yang dipegang oleh Shanghai yaitu 613 (Ali, 2013).

Terdapat beberapa hasil penelitian, baik dari tingkat nasional maupun internasional mengatakan bahwa secara klasikal kemampuan pemecahan masalah matematis pada siswa SMA belum mencapai taraf memuaskan (Ibrahim, 2008). Terdapat banyak faktor yang menyebabkan siswa SMA tidak mencapai taraf memuaskan dalam belajar Matematika. Salah satunya adalah adanya perasaan takut dan tegang saat menghadapi ujian, khususnya ujian Matematika. Beberapa siswa remaja SMA kadang menyikapi 
ujian sebagai suatu permasalahan dalam hidupnya, ia akan merasa sangat malu karena tidak mendapatkan nilai yang bagus dan merasa merasa tidak yakin dengan persiapan yang dimilikinya. Perasaan takut atau tegang dalam menghadapi suatu persoalan tersebut disebut dengan kecemasan pada mata pelajaran Matematika (Wicaksono \& Saufi, 2008).

Solikah (2012) mengatakan bahwa kecemasan sebagai keadaan mental yang ditandai dengan kekhawatiran dan perasaan tidak baik yang tidak dapat dihindari oleh seseorang. Fennema dan Sherman (dalam Zakaria \& Nordin, 2008) mendefinisikan kecemasan terhadap pelajaran Matematika adalah perasaan yang kuat serta melibatkan rasa takut ketika dihadapkan dengan kemungkinan menangani masalah Matematika. Menurut DSM-IV-TR kecemasan diasumsikan sekurang-kurangnya dengan kegelisahan, mudah merasa lelah, sulit berkonsentrasi, mudah marah, otot yang tegang, dan gangguan tidur (APA, 2000).

Selain faktor kecemasan terhadap hasil belajar Matematika, Wicaksono dan Saufi (2008) mengatakan bahwa dalam menghadapi pelajaran Matematika siswa SMA merasa tidak yakin dengan persiapan mereka dalam menghadapi ujian Matematika. Salah satu penyebab perasaan tidak yakin ini karena merasa bahwa mereka tidak mampu dalam menghadapi soal-soal Matematika dan kurangnya persiapan, sehingga siswa merasa tidak yakin untuk mendapatkan nilai yang memuaskan dalam pelajaran Matematika (Wicaksono \& Saufi, 2008).

Perasaan tidak yakin tersebut dapat juga disebut dengan self-efficacy yang rendah (Baron \& Branscombe, 2014). Self-efficacy merupakan penilaian individu terhadap kemampuan atau kompetensinya untuk melakukan suatu tugas, mencapai suatu tujuan dan menghasilkan sesuatu (Baron \& Branscombe, 2014). Bandura (dalam Mukhid, 2009) mengatakan bahwa Self-efficacy merupakan judgement seseorang atas kemampuan untuk merencanakan dan melaksanakan tindakan yang mengarah pada pencapaian tujuan tertentu. Dapat disimpulkan bahwa self-efficacy merupakan suatu keyakinan individu dalam menyelesaikan suatu masalah dengan hasil yang baik.

\section{Tinjauan Teoretis}

Kecemasan Matematika. Terdapat beberapa pengertian mengenai Kecemasan Matematika. Menurut Fennema dan Sherman (dalam Zakaria \& Nordin, 2008) Kecemasan Matematika merupakan perasaan yang melibatkan rasa takut ketika dihadapkan dengan kemungkinan menangani permasalahan Matematika. Ashcraft (dalam Mutawah, 2015) mendefinisikan Kecemasan Matematika sebagai perasaan tegang, cemas, atau takut dalam memanipulasi angka-angka dan memecahkan permasalahan Matematika. Menurut Sheggield dan Hunt (dalam Mutawah, 2015) mengatakan bahwa kecemasan ini sama seperti tipe kecemasan lainnya, siswa akan merasakan detak jantung yang lebih cepat dan kuat, serta mereka memiliki kepercayaan bahwa mereka tidak mampu untuk menyelesaikan permasalahan Matematika.

Rounds dan Hendel (dalam Suinn \& Winston, 2003) Mengatakan bahwa terdapat dua dimensi dalam kecemasan Matematika, yaitu mathematics test anxiety dan numerical anxiety. Mathematics test anxiety mengacu pada kejadian sehari-hari dengan situasi kongkrit yang membutuhkan beberapa bentuk manipulasi angka seperti penambahan 
dan perkalian. Dimensi tersebut berbeda dengan dimensi numerical anxiety yang merefleksikan pendekatan tentang antisipasi, mempelajari, dan menerima hasil terkait dengan Matematika (Rounds \& Hendel, 1980).

Numerical anxiety adalah perasaan tegang dan takut yang mengganggu kinerja Matematika seperti dalam manipulasi angka dan pemecahan masalah Matematika dalam situasi akademik dan kehidupan sehari-hari. Hampir setiap orang akan memiliki numerical anxiety dan sebagian besar siswa juga memiliki kecemasan numerik tersebut. Efek dari kecemasan numerik ini cukup nyata bagi siswa. Kecemasan ini akan berdampak negatif terhadap kemampuan dalam menyelesaikan tugas-tugas Matematika, hal ini juga akan menyebabkan siswa sulit berkonsentrasi dalam pelajaran Matematika (Morada, 2015).

Self-Efficacy. Omrod (2008) mendefiniskan self-efficacy sebagai keyakinan bahwa seseorang mampu menjalankan perilaku tertentu atau mencapai tujuan tertentu. Menurut Woolfolk (dalam Andiny, 2008) mengatakan bahwa secara umum self-efficacy adalah penilaian seseorang terhadap dirinya sendiri atau tingkat keyakinan mengenai seberapa besar kemampuannya dalam mengerjakan suatu tugas tertentu untuk mencapai hasil tertentu. Bandura (dalam Feist \& Feist, 2013) mendefinisikan self-efficacy sebagai kepercayaan seseorang pada kemampuannya untuk melakukan kontrol terhadap peristiwa yang sedang mereka hadapi. Albert Bandura juga mengatakan bahwa kepercayaan masyarakat dalam personal efficacy memengaruhi hal-hal yang mereka kejar (Feist \& Feist, 2013). Bandura (1997) mengatakan bahwa terdapat tiga dimensi penting dalam self-efficacy setiap individu. Adapun dimensi tersebut adalah: (a) level, (b) generality, dan (c) strength. Berikut penjelasan masing-masing dimensi self-efficacy.

Level. Dimensi ini berkaitan dengan tingkatan kesulitan tugas. Persepsi individu akan berbeda dalam memandang tingkat kesulitan dari suatu tugas. Individu yang memiliki self-efficacy tinggi akan cenderung memilih mengerjakan tugas-tugas yang sifatnya sulit dibandingkan dengan yang sifatnya mudah. Individu akan melakukan kegiatan yang dirasa mampu untuk dilaksanakan terutama kegiatan yang diperkirakan di luar batas kemampuan yang dimiliki. Semakin tinggi tingkat kesulitan tugas maka semakin tinggi pula tuntutan self-efficacy individu tersebut.

Generality. Dimensi generality menjelaskan tentang keyakinan individu untuk menyelesaikan tugas-tugas tertentu dengan tuntas dan baik. Hal ini berkaitan dengan bidang pencapain individu seperti penguasaan tugas, penguasaan materi, serta mengatur waktu. Tidak semua individu mampu melakukan tugas dalam beberapa bidang tertentu akan tetapi individu yang memiliki self-efficacy yang tinggi cenderung menguasai tugas dari berbagai bidang berbeda. Sementara itu, individu yang memiliki self-efficacy rendah hanya menguasai tugas dari bidang-bidang tertentu saja.

Strength. Dimensi ini berkaitan erat dengan kekuatan akan keyakinan yang dimiliki oleh individu. Hal ini meliputi gigih dalam belajar, gigih dalam menyelesaikan tugas-tugas, serta konsistensi dalam mencapai tujuan. Individu yang memiliki keyakinan yang kuat akan dalam dirinya tentu akan berusaha untuk mencapai tujuan yang ingin dicapai. Namun bagi individu yang tidak memiliki keyakinan yang kuat, maka individu tersebut akan mudah menyerah untuk berusaha mencapai tujuan yang telah ditetapkannya. 
Hasil Belajar Matematika. Hasil belajar seringkali digunakan sebagai tolak ukur untuk mengetahui ukuran seberapa jauh seseorang menguasai bahan yang diajarkan. Hasil belajar berasal dari dua kata yaitu "hasil" dan "belajar". Hasil merupakan suatu perolehan akibat dilakukannya suatu aktivitas atau proses yang mengakibatkan berubahnya input secara fungsional (Purwanto, 2009). Sedangkan belajar adalah tahapan perubahan seluruh tingkah laku individu yang relatif menetap sebagai hasil pengalaman dan interaksi dengan lingkungan yang melibatkan proses kognitif (Syah, 2007).

Matematika merupakan salah satu pelajaran yang diberikan di dalam proses belajar mengajar di sekolah sehingga Matematika mempunyai nilai atau hasil belajarnya akan terlihat di rapot sekolah siswa. Terdapat beberapa definisi yang menjelaskan tentang Matematika. Suriasumantri (2009) mengatakan bahwa Matematika adalah bahasa yang melambangkan serangkaian makna dari pernyataan yang ingin kita sampaikan. Pada penelitian ini, untuk melakukan perhitungan terkait dengan kemampuan Matematika siswa SMA pada mata pelajaran Matematika maka akan dilihat melalui hasil belajar Matematika pada semester satu siswa SMA tersebut. Hasil belajar tersebut merupakan nilai rapot siswa yang siswa dapatkan setelah mereka melalui proses belajar Matematika selama enam bulan belajar Matematika. Hal ini dilakukan karena dalam penelitian ini tidak mengukur kecemasan Matematika dan self-efficacy secara umum namun hanya dikhususkan untuk mengukur kecemasan Matematika dan self-efficacy pada mata pelajaran matematika siswa SMA.

\section{METODE PENELITIAN}

Subyek penelitian yang diambil merupakan individu yang berada di usia remaja. Menurut Erikson (dalam King, 2013) tahap perkembangan remaja berada pada rentang usia 11-20 tahun. Pada penelitian ini peneliti mendapatkan subyek penelitian dengan rentang usia 14-18 tahun yang bersekolah di SMA X Kota Palangka Raya. Subyek dengan usia 14-18 tahun ini berada di tingkat pendidikan SMA kelas X, XI, dan XII.

Pada penelitian ini peneliti menggunakan teknik pengambilan data non-probability sampling, yaitu teknik sampling yang tidak memberi peluang atau kesempatan sama bagi setiap unsur atau anggota populasi untuk dipilih menjadi sampel. Teknik sampling yang peneliti gunakan adalah teknik purposive sampling yang berarti bahwa sampel yang diambil dengan berdasarkan pertimbangan tertentu (Sugiyono, 2011).

Pada tahun 1972 Ricardson dan Suinn membuat sebuah alat ukur The Mathematics Anxiety Rating Scale (MARS) yang terdiri dari 98 item. Pada tahun 2003 Suinn dan Winston kemudian mengembangkan alat ukur MARS tersebut yang dapat dilihat dalam jurnal The Mathematics Anxiety Rating Scale: A Brief Version (Suinn \& Winston, 2003).

Alat ukur ini terdiri dari dua dimensi, yaitu mathematics test anxiety dan numerical anxiety. Dimensi mathematics test anxiety terdiri dari 12 butir yang pernyataannya semua bersifat positif. Melalui hasil uji reliabilitas dengan SPSS diketahui bahwa alat ukur MARS dimensi mathematics test anxiety memiliki koefisien alpha cronbach 
sebesar 0,831. Hasil analisa menunjukkan bahwa dari 12 butir pernyataan yang ada, keseluruhan butir tidak ada yang memiliki nilai corrected item-total correlation yang lebih kecil dari 0,2, sehingga tidak ada butir yang perlu dibuang. Jadi total butir yang valid dan reliabel yaitu 12 butir.

Dimensi selanjutnya dalam alat ukur MARS adalah dimensi numerical anxiety. Dimensi ini terdiri dari 18 butir bersifat positif dan tidak ada butir negatif. Setelah uji reliabilitas dan validitas dengan SPSS diketahui bahwa ada satu butir dalam alat ukur MARS dimensi numerical anxiety yang perlu dibuang, yaitu butir nomor delapan. Melalui uji reliabilitas diketahui bahwa alat ukur MARS dimensi numerical anxiety memiliki koefisien alpha cronbach sebesar 0,832, namun setelah satu butir buruk dibuang, alpha cronbach menjadi 0,847 . Hasil analisa menujukkan bahwa dari 18 butir pernyataan yang ada, terdapat satu butir yang menunjukkan nilai corrected item-total correlation lebih kecil dari 0,2 . Jadi butir pernyataan yang tersisa menjadi 17 butir positif.

Alat ukur yang digunakan untuk mengukur self-efficacy dikembangkan oleh Au Le Hong pada tahun 2012 (Hong, 2012). Alat ukur ini dikembangkan berdasarkan teori self-efficacy Albert Bandura. Alat ukur ini terdiri dari 10 butir yang di dalamnya terdapat tujuh pernyataan positif dan tiga pernyataan negatif. Alat ukur ini terdiri dari tiga dimensi, yaitu (a) level, (b) generality, dan (c) strength. Dimensi level terdiri dari dua butir yang pernyataannya bersifat positif.

Melalui hasil uji reliabilitas dengan SPSS diketahui bahwa alat ukur self-efficacy dimensi level memiliki koefisien alpha cronbach sebesar 0,778. Hasil analisa menunjukkan bahwa dari dua butir pernyataan yang ada, keseluruhan butir tidak ada yang memiliki nilai corrected item-total correlation yang lebih kecil dari 0,2 , sehingga tidak ada butir yang perlu dibuang. Jadi dari total butir yang valid dan reliabel yaitu sebanyak dua butir.

Dimensi kedua dalam self-efficacy adalah dimensi generality. Dimensi ini terdiri dari dua item bersifat positif. Melalui hasil uji reliabilitas dan validitas dengan SPSS diketahui bahwa alat ukur self-efficacy dimensi generality memiliki koefisien alpha cronbach sebesar 0,811. Hasil analisa menunjukkan bahwa dari dua butir pernyataan yang ada, keseluruhan butir tidak ada yang memiliki nilai corrected item-total correlation yang lebih kecil dari 0,2 , sehingga tidak ada butir yang perlu dibuang. Jadi total butir yang valid dan reliabel yaitu dua butir.

Dimensi ketiga dalam self-efficacy adalah dimensi strength. Dimensi strength ini memiliki enam butir pernyataan yaitu tiga pernyataan positif dan tiga pernyataan negatif. Melalui hasil uji reliabilitas dan validitas dengan SPSS diketahui bahwa alat ukur self-efficacy dimensi strength memiliki koefisien alpha cronbach sebesar 0,719. Hasil analisa menunjukkan bahwa dari enam butir pernyataan yang ada, keseluruhan butir tidak ada yang memiliki nilai corrected item-total correlation yang lebih kecil dari 0,2 , sehingga tidak ada butir yang perlu dibuang. Jadi dari total butir yang valid dan reliabel yaitu sebanyak enam butir. 


\section{HASIL DAN PEMBAHASAN}

\section{Gambaran Partisipan}

Berdasarkan data yang diperoleh mengenai jenis kelamin para partisipan, dari total 467 orang partisipan. Partisipan yang berjenis kelamin laki-laki berjumlah 178 orang (38,1 $\%)$, dan partisipan yang berjenis kelamin wanita berjumlah 289 orang $(61,9 \%)$. Partisipan yang berusia 14 tahun berjumlah 9 orang (1,9\%), partisipan yang berusia 15 tahun berjumlah 145 orang (31\%), partisipan yang berusia 16 tahun berjumlah 254 orang $(54,4 \%)$, partisipan yang berusia 17 tahun berjumlah 57 orang (12,2\%), dan partisipan yang berusia 18 tahun berjumlah 2 orang (4\%).

\section{Gambaran Data Variabel}

Gambaran data untuk dimensi-dimensi pada variabel Kecemasan Matematika menggunakan skala satu sampai dengan lima memiliki mean hipotetic alat ukur yaitu tiga. Adapun dimensi pada variabel ini terdiri: (a) mathematics test anxiety, dan (b) numerical anxiety.

Mathematics test anxiety. Hasil dari perhitungan menunjukkan bahwa dimensi mathematics test anxiety memiliki skor mean empiric sebesar 3,3203. Salah satu definisi terkait dengan mathematics test anxiety mengatakan bahwa dimensi ini mengacu pada kejadian sehari-hari dengan situasi kongkrit yang membutuhkan beberapa bentuk manipulasi angka seperti penambahan dan perkalian (Rounds \& Hendel, 1980).

Indikator dari dimensi ini mengatakan bahwa perasaan cemas akan muncul ketika seseorang dihadapkan dengan tes Matematika (Seng, 2015). Dengan kata lain melalui dimensi ini dapat dilihat bahwa subyek dalam penelitian mempunyai tingkatan kecemasan Matematika yang tinggi ketika dihadapkan dengan ujian Matematika. Hal ini terlihat dari data yang menunjukkan skor mean empiric $(3,3203)$ lebih besar dari skor mean hipotetic $(3,00)$.

Numerical anxiety. Gambaran data untuk dimensi numerical anxiety dari variabel Kecemasan Matematika memiliki skor mean empiric alat ukur yaitu 2,3356. Hal ini menandakan bahwa skor mean hipotetic lebih besar dari skor mean empiric. Dimensi numerical anxiety merupakan perasaan tegang dan takut yang mengganggu kinerja Matematika seperti dalam manipulasi angka dan pemecahan masalah Matematika dalam situasi akademik dan dalam kehidupan sehari-hari (Morada, 2015).

Melalui penjelasan di atas dapat disimpulkan bahwa dalam menghadapi pelajaran Matematika subyek akan merasa cemas namun tidak merasa tegang dan takut dalam menghadapi Matematika, dengan kata lain indikator dimensi numerical anxiety subyek tergolong rendah. Hal ini terlihat dari data yang menunjukkan skor mean empiric $(2,3356)$ lebih kecil dari skor mean hipotetic $(3,00)$. 
Tabel 1. Gambaran Data Variabel Dimensi Kecemasan Matematika

\begin{tabular}{ccc}
\hline Dimensi & Mean & Standar Deviasi \\
\hline Mathematics Test Anxiety & 3,3203 & 0,59624 \\
Numerical Anxiety & 2,3356 & 0,48418 \\
\hline
\end{tabular}

Gambaran data untuk dimensi pada variabel self-efficacy menggunakan skala satu sampai dengan lima memiliki mean hipotetic alat ukur yaitu tiga. Adapun dimensi tersebut adalah: (a) level, (b) generality, dan (c) strength.

Level. Hasil dari perhitungan menunjukkan bahwa dimensi level memiliki skor mean empiric sebesar 3,0964. Bandura (1997) mengatakan bahwa dalam dimensi level ini individu yang memiliki self-efficacy tinggi akan cenderung memilih mengerjakan tugastugas yang sifatnya sulit dibandingkan dengan yang sifatnya mudah. Hal ini dapat berarti bahwa subyek penelitian mempunyai self-efficacy yang tinggi dalam mengerjakan tugas-tugas yang sifatnya lebih sulit. Melalui dimensi ini dapat dilihat juga bahwa dimensi level subyek tergolong tinggi, dengan menunjukkan skor mean empiric $(3,0964)$ lebih besar dari skor mean hipotetic $(3,00)$.

Generality. Hasil dari perhitungan menunjukkan bahwa dimensi generality memiliki skor mean empiric sebesar 3,3630. Dimensi generality itu sendiri menjelaskan tentang keyakinan individu untuk menyelesaikan tugas-tugas tertentu dengan tuntas dan baik (Bandura, 1997). Dengan kata lain melalui dimensi ini dapat dilihat bahwa dimensi generality subyek tergolong tinggi. Dari hasil temuan tersebut dapat dikatakan bahwa subyek penelitian mempunyai self-efficacy yang tinggi dalam menyelesaikan tugastugas terkait dengan pelajaran Matematika dengan baik dan tuntas. Hal ini terlihat dari skor mean empiric $(3,3630)$ yang lebih besar dari pada skor mean hipotetic $(3,00)$.

Strength. Hasil dari perhitungan menunjukkan bahwa dimensi strength memiliki skor mean empiric sebesar 3,5810. Dimensi ini berkaitan erat dengan kekuatan akan keyakinan yang dimiliki oleh individu. Hal ini meliputi gigih dalam belajar, gigih dalam menyelesaikan tugas-tugas, serta konsistensi dalam mencapai tujuan (Bandura, 1997). Dengan kata lain, ditinjau dari mean empiric $(3,5810)$ lebih besar dari pada skor mean hipotetic $(3,00)$ dimensi strength yang dimiliki subyek tergolong tinggi. Hal ini berarti bahwa subyek penelitian mempunyai self-efficacy yang tinggi dan konsisten dalam menyelesaikan tugas-tugas terkait dengan pelajaran Matematika. Gambaran dimensidimensi self-efficacy dapat dilihat pada lampiran 13b dan tabel 4.6 berikut.

Tabel 2. Variabel Dimensi Self-Efficacy

\begin{tabular}{lll}
\hline Dimensi & Mean & Standar Deviasi \\
\hline Level & 3,0964 & 0,80391 \\
Generality & 3,3630 & 0,75727 \\
Strength & 3,5810 & 0,64737 \\
\hline
\end{tabular}

\section{Uji Normalitas Variabel Penelitian}

Berdasarkan hasil uji one sample $K-S$, terlihat bahwa hasil belajar Matematika atau nilai Matematika subyek tidak terdistribusi secara normal. Hal ini dilihat dari hasil pengujian yang menunjukkan nilai $p=0,002$. Dimensi ini dikatakan tidak normal karena memiliki nilai lebih kecil dari $0,05(p<0,05)$ sebagai ketentuan uji normalitas. 
Tabel 3. Hasil Uji Normalitas Nilai Matematika

\begin{tabular}{ccc}
\hline Variabel & Kolmogorov-Smirnov & $p$ \\
\hline Nilai & 1,847 & 0,002 \\
\hline
\end{tabular}

Pengujian yang kedua kemudian dilakukan pada variabel Kecemasan Matematika. Hasil uji menunjukkan bahwa variabel Kecemasan Matematika terdistribusi secara normal. Hal tersebut dikarenakan dimensi pada variabel kecemasan pada pelajaran Matematika memiliki nilai $p$ pada pengujian Kolmogorov-Smirnov lebih besar dari 0,05 $(p>0,05)$.

Tabel 4. Hasil Uji Normalitas Kecemasan Matematika

\begin{tabular}{ccc}
\hline Dimensi & Kolmogorov-Smirnov & $p$ \\
\hline Mathematics Test Anxiety & 1,343 & 0,054 \\
Numerical Anxiety & 1,063 & 0,208 \\
\hline
\end{tabular}

Selanjutnya, berdasarkan hasil uji one sample $K-S$, terlihat bahwa variabel self-efficacy tidak terdistrubsi secara normal. Hal tersebut dikarenakan dimensi pada variabel selfefficacy memiliki nilai $p$ pada pengujian Kolmogorov-Smirnov lebih kecil dari 0,05 ( $p<$ $0,05)$.

Tabel 5. Hasil Uji Normalitas Self-Efficacy

\begin{tabular}{ccc}
\hline Dimensi & Kolmogorov-Smirnov & $p$ \\
\hline Level & 4,962 & 0,000 \\
Generality & 3,772 & 0,000 \\
Strength & 1,538 & 0,018 \\
\hline
\end{tabular}

\section{Pengujian Hipotesis Penelitian}

Berdasarkan hasil uji korelasi dengan menggunakan spearman correlation, diketahui bahwa nilai Matematika memiliki hubungan signifikan dengan Kecemasan Matematika. Hal ini diketahui dari nilai $r=-0,196$ dan $p=0,000<0,05$, dengan demikian dapat dikatakan ada hubungan siginifikan yang negatif antara nilai Matematika siswa atau hasil belajar dengan Kecemasan Matematika. Semakin tinggi kecemasan siswa dalam menghadapi pelajaran Matematika maka semakin rendah hasil belajar Matematika siswa, begitu pula sebaliknya semakin rendah kecemasan Matematika siswa dalam menghadapi pelajaran Matematika maka semakin tinggi hasil belajar Matematika siswa.

Selanjutnya untuk variabel self-efficacy memiliki hubungan signifikan dengan hasil belajar Matematika siswa. Hal ini dapat diketahui dari nilai $r=0,210$ dan $p=0,000<$ 0,05 , dengan demikian dapat dikatakan bahwa ada hubungan signifikan yang positif antara hasil belajar Matematika siswa dengan self-efficacy. Semakin tinggi self-efficacy yang dimiliki oleh siswa maka semakin tinggi juga hasil belajar Matematika siswa, begitu juga sebaliknya semakin rendah self-efficacy siswa maka semakin rendah pula hasil belajar Matematika yang dimiliki siswa.

Berdasarkan hasil perhitungan di atas dapat disimpulkan bahwa hipotesis awal dapat diterima dengan mengatakan terdapat hubungan antara kecemasan Matematika pada mata pelajaran Matematika dan self-efficacy dengan hasil belajar Matematika siswa SMA. Hubungan tersebut berupa hubungan signifikan yang negatif antara hasil belajar 
Matematika dengan kecemasan Matematika dan hubungan signifikan yang positif antara hasil belajar Matematika dengan self-efficacy.

Tabel 6. Hasil Uji Hipotesis Penelitian

\begin{tabular}{lll}
\hline Hubungan antara hasil belajar Matematika dengan & $p$ & $r$ \\
\hline Kecemasan Matematika & 0,000 & $-0,196$ \\
Self-efficacy & 0,000 & 0,210 \\
\hline
\end{tabular}

\section{KESIMPULAN}

Berdasarkan hasil analisis data dapat disimpulkan bahwa penelitian tentang hubungan antara Kecemasan Matematika dan self-efficacy dengan hasil belajar Matematika siswa SMA mempunyai hubungan signifikan. Variabel Kecemasan Matematika dan hasil belajar Matematika mempunyai hubungan signifikan yang negatif. Hal ini berarti bahwa semakin tinggi Kecemasan Matematika maka semakin rendah juga hasil belajar Matematika siswa SMA. Hasil signifikan negatif ini juga dapat berarti bahwa semakin rendah Kecemasan Matematika maka akan semakin tinggi hasil belajar Matematika siswa SMA.

Berdasarkan analisis data juga dapat disimpulkan bahwa terdapat hubungan signifikan positif antara self-efficacy dan variabel hasil belajar belajar Matematika. Hal ini berarti bahwa semakin tinggi self-efficacy siswa dalam menyelesaikan tugas-tugas terkait dengan Matematika maka akan semakin tinggi juga hasil belajar Matematika siswa. Hasil signifikan positif ini juga berarti bahwa semakin rendah self-efficacy yang dimiliki oleh siswa yang berkaitan dengan Matematika maka semakin rendah juga hasil belajar Matematika siswa SMA.

\section{Pembahasan}

Hasil penelitian ini sejalan dengan penelitian yang dilakukan oleh Zakaria dan Nordin (2008) bahwa terdapat hubungan signifikan negatif antara hasil belajar dengan kecemasan Matematika pada siswa SMA di Selanggor, Malaysia. Hasil penelitian tersebut mengungkapkan bahwa siswa yang memiliki hasil belajar yang tinggi akan cenderung memiliki level kecemasan yang lebih rendah, sedangkan siswa dengan hasil belajar yang rendah memiliki level kecemasan yang lebih tinggi (Zakaria \& Nordin, 2008).

Namun demikian, hasil penelitian ini tidak sejalan dengan penelitian yang dilakukan Khaeriyah (2003) yang mengatakan bahwa tidak terdapat hubungan antara kecemasan Matematika dan hasil belajar siswa di Makassar. Hal ini dapat berarti bahwa walaupun penelitian yang dilakukan di suatu kota di Indonesia yaitu di Palangka Raya dan Makassar tidak menutup kemungkinan terjadi perbedaan hasil penelitian. Hasil penelitian yang berbeda ini juga bisa saja terjadi karena perbedaan pengaruh lingkungan dan berubahnya pola pikir berdasarkan perbedaan waktu penelitian yang cukup lama yaitu antara siswa SMA pada tahun 2003 dan siswa SMA tahun 2017.

Berdasarkan hasil wawancara dengan guru matematika di sekolah pengambilan data penelitian dikatakan bahwa terdapat beberapa siswa yang perlu perhatian khusus dari guru untuk memahami pelajaran matematika. Beberapa siswa tersebut merasa bahwa matematika merupakan pelajaran yang sangat sulit dipahami. Hal tersebut sejalan 
dengan pernyataan dari hasil penelitian yang dilakukan oleh Ghufron dan Suminta (2013) yang menemukan hasil bahwa Matematika dipandang sebagai stressor utama dalam proses belajar siswa. Namun, ada beberapa siswa juga yang bisa mengerti dengan cepat pelajaran matematika di sekolah tempat penelitian yang dilakukan oleh peneliti. Hal ini dimanfaatkan guru matematika untuk membuka kelas "tutor" antar siswa untuk menerapkan sistem belajar mengajar pelajaran matematika.

Hasil penelitian juga ditemukan bahwa walaupun siswa merasa cemas dalam menghadapi ujian matematika, siswa tidak merasa bahwa itu merupakan perasaan yang dapat menganggu kinerja mereka dalam menghadapi pelajaran Matematika atau ujian Matematika. Hal ini terjadi karena siswa dalam penelitian ini mempunyai self-efficacy yang tinggi dalam menghadapi pelajaran Matematika dilihat dari skor mean hipotetik dan mean empiric setiap dimensi, sehingga siswa merasa yakin mampu menyelesaikan persoalan Matematika. Pernyataan diatas didukung oleh analisis data tambahan yang menemukan bahwa terdapat hubungan signifikan negatif antara kecemasan Matematika dan self-efficacy. Semakin tinggi kecemasan Matematika maka semakin rendah selfefficacy siswa, begitu pula sebaliknya semakin tinggi self-efficacy siswa maka semakin rendah kecemasan Matematikanya.

Berdasarkan hasil uji pada variabel self-efficacy dan hasil belajar Matematika ditemukan bahwa terdapat hubungan signifikan positif antara kedua variabel tersebut. Hasil ini mendukung pernyataan Albet Bandura (dalam Feist \& Feist, 2013) yang mengatakan bahwa dengan mempunyai self-efficacy seseorang dapat mengontrol peristiwa yang sedang mereka hadapi. Hal tersebut berarti bahwa dengan memiliki keyakinan diri yang tinggi siswa dapat mengontrol dirinya dalam menghadapi mata pelajaran Matematika sehingga mendapatkan hasil belajar yang tinggi.

Bandura (1997) mengatakan bahwa orangtua dan guru sering memandang berbeda terhadap kemampuan laki-laki dan perempuan. Orangtua menganggap bahwa perempuan lebih sulit untuk mengikuti pelajaran dibanding laki-laki, walaupun prestasi akademik mereka tidak terlalu berbeda. Semakin perempuan menerima perlakuan steorotipe gender ini, maka semakin rendah penilaian perempuan mereka terhadap kemampuan dirinya. Hasil uji dalam penelitian ini menunjukkan hal yang berbeda dengan teori dengan menemukan hasil bahwa self-efficacy perempuan lebih tinggi daripada self-efficacy laki-laki dalam menghadapi pelajaran Matematika.

\section{Saran Teoretis}

Penelitian ini dapat memberikan manfaat terutama untuk pengembangan ilmu Psikologi, khususnya pada Psiologi Pendidikan, dan Psikologi Remaja. Saran peneliti agar bidang ilmu psikologi dapat memberikan seminar bagi siswa SMA agar dapat menghilangkan kecemasannya pada mata pelajaran Matematika dan meningkatkan self-efficacy siswa. Training juga dapat dilakukan kepada guru yang mengajar di sekolah agar dapat mengajar siswa dengan menaikan self-efficacy siswa dan tidak membuatnya cemas dalam pelajaran tertentu.

Saran peneliti untuk penelitian selanjutnya agar mencari faktor penyebab munculnya Kecemasan Matematika di sekolah tempat dilakukannya penelitian atau di SMA lainnya. Faktor tersebut juga dapat dikhususkan pada bagaimana pengaruh atau 
hubungan antara cara gaya guru mengajar Matematika di kelas dengan hasil belajar Matematika siswanya. Selain itu, untuk peneliti lain yang memilih menggunakan alat ukur MARS sebaiknya lebih memperhatikan faktor guru atau faktor yang berkaitan dengan sekolah untuk mengukur kecemasan Matematikanya. Peneliti juga menyarankan kepada peneliti selanjutnya untuk bisa membuat alat ukur yang dikhususkan mengukur kecemasan Matematika pada mata pelajaran Matematika sesuai dengan budaya di Indonesia.

Saran untuk penelitian selanjutnya terkait dengan variabel ini agar dapat melakukan penelitian dengan membandingkan pengaruh budaya organiasi atau lingkungan selfefficacy terhadap kecemasan dan self-efficacy siswa SMA. Saran selanjutnya, untuk berbagai penelitian yang mengambil subyek siswa SMA agar dapat mengambil data penelitian pada semester satu akhir atau semester dua awal. Hal ini karena pada ada beberapa sekolah yang tidak mengijinkan jika pengambilan data pada siswa kelas XII pada pertengahan semester dua karena siswa kelas XII sedang persiapan UN.

\section{Saran Praktis}

Berdasarkan hasil penelitian ini dapat diberikan saran kepada beberapa pihak terkait, yaitu (a) guru, (b) orangtua, dan (c) siswa.

Pertama, guru. Dari pihak guru atau pihak sekolah agar dapat memahami bahwa pelajaran Matematika merupakan pelajaran yang dapat membuat siswa menjadi cemas. Hal ini dapat diatasi dengan cara guru memodifikasi cara mengajarnya agar Matematika tidak lagi menakutkan bagi siswa SMA. Guru dapat membuat siswa menyukai pelajaran Matematika dengan cara mengajar yang menyenangkan seperti menghafal rumus dengan games sederhana serta mengajarkan siswa untuk mengerjakan soal dengan cara singkat dan dapat dipahami dengan mudah oleh siswa. Selain itu, guru juga dapat memberikan seminar terkait dengan motivasi belajar kepada siswa untuk meningkatkan self-efficacy atau keyakinan diri siswa dalam belajar Matematika.

Kedua, orangtua. Saran bagi orangtua siswa adalah agar dapat memberikan pelajaran tambahan bagi siswa di luar sekolah. Pelajaran tambahan tersebut dapat dilakukan dengan mendaftarkan anaknya untuk mengikuti les Matematika atau bimbingan belajar Matematika. Selain itu, agar dapat menurunkan kecemasan siswa terhadap pelajaran Matematika dan meningkatkan self-efficacy siswa, orangtua dapat memberikan perhatian terhadap anaknya dengan menanyakan pelajaran apa saja yang telah dipelajari di sekolah dan tentunya memberikan semangat kepada anaknya.

Ketiga, siswa. Saran bagi siswa agar dapat mencoba mengubah pandangan sebelumnya yang mengatakan bahwa Matematika sangat sulit untuk dipahami, agar dapat beranggapan bahwa Matematika adalah pelajaran yang mudah. Hal ini dapat membuat siswa tidak takut terlebih dulu dengan pelajaran Matematika dan berusaha memahami pelajaran Matematika. Siswa harus bisa memotivasi diri agar dapat yakin mampu dalam menyelasaikan tugas-tugas terkait dengan pelajaran Matematika.

\section{REFERENSI}

Ali, F. R. U. (2013, Desember). Siswa Indonesia peringkat 64 dari 65 negara, tapi paling bahagia di Dunia. Kompasiana. Diunduh dari 
http://www.kompasiana.com/www.febrialdiali.blogspot.com/siswa-indonesiaperingkat-64-dari-65-negara-tapi-paling-bahagia-didunia_552b89306ea83485098b4595

American Psychiatric Association. (2000). Diagnostic and Statistical Manual of Mental Disorders (4th ed., text rev.). DOI:10.1176/appi.books.9780890423349.

Andiny, L. (2008). Perbedaan self-efficacy. Jakarta: FPSI UI.

Bandura, Albert. (1997). Self Efficacy : The Exercise Of Control. New York : W.H. Freeman and Company.

Baron, R. A. \& Branscombe, N. R. (2014). Social psyhcology $\left(13^{\text {th }}\right.$ ed.). USA: Pearson.

Feist, J. \& Feist, J. G. (2013). Theories of personality ( $8^{\text {th }}$ ed.). Singapore: McGrawHill.

Ghufron, M. N. \& Suminta, R. R. (2013, Juni). Efikasi diri dan hasil belajar matematika: Meta-analisis. Buletin Psikologi. 21(1). 20-30. Diunduh dari https://www.google.com/url? sa=t\&rct=j\&q=\&esrc=s\&source=web\&cd=2\&cad= rja\&uact=8\&ved=0ahUKEwj8zfDL1 arPAhXBvI8KHa5qCvYQFggnMAE\&url $=$ https $\% 3 \mathrm{~A} \% 2 \mathrm{~F} \% 2$ Fjurnal.ugm.ac.id\%2Fbuletinpsikologi\%2Farticle $\% 2$ Fdownl oad\%2F9843\%2F7411\&usg=AFQjCNEe6s_tvc1ry9VJeT4fywHpDAzjWg\&sig 2=Mmh3inX0wOZ9FeGs4zgPew\&bvm=bv.133700528,d.c2I

Hong, A. L. (2012). Pengaruh pelatihan metode gasing untuk meningkatkan selfefficacy, motivasi belajar dan prestasi belajar matematika pada siswa SD. Tesis. Jakarta: Universitas Tarumanagara

Ibrahim. (2008). Pembelajaran matematika untuk meningkatkan kemampuan pemecahan masalah matematis siswa Sekolah Menengah Atas. Semnas Matematika dan Pendidikan Matematika. 90-100. Diunduh dari http://eprints.uny.ac.id/6908/1/P-7\%20Pendidikan\%20(Ibrahim).pdf

Kementerian Pendidikan dan Kebudayaan. (2014). Laporan hasil ujian nasional tahun 2014. Jakarta: Pusat Penilaian Pendidikan.

Khaeriyah, Y. (2003). Hubungan antara kecemasan dan minat belajar matematika dengan prestasi belajar matematika. Tesis. Yogyakarta: Universitas Gadjah Mada. Diunduh dari http://etd.repository.ugm.ac.id/index.php?mod=penelitian_detail\&sub=Penelitia nDetail\&act=view\&typ $=$ html\&buku_id=21536\&obyek_id $=4$

King, L. A. (2013). The science of psychology: A appreciative view ( $2^{\text {nd }}$ ed.). New York: McGraw-Hill.

Mahmood, S. \& Khatoon, T. (2011). Development and Validation of the Mathematics Anxiety Scale for Secondary and Senior Secondary School Students. British Journal of Arts and Social Sciences, 2(2), 169-179. Retrieved from http://www.bjournal.co.uk/paper/BJASS_2_2/BJASS_02_02_07.pdf

Morada, M. H. D. (2015, December). Correlation of numerical anxiety and mathematics performance. Asia Pasific Journal of Multidisciplinary Research, 3(5), 45-43. Retrieved from http://www.apjmr.com/wp-content/uploads/2016/04/APJMR2015-3.5.3.06.pdf

Mukhid, A. (2009). Self-Efficacy: Persepektif teori kognitif sosial dan implikasinya terhadap pendidikan. Tadrîs. 4(1). 105-122. Diunduh dari https://www.google.com/url? sa=t\&rct=j\&q=\&esrc=s\&source=web\&cd=3\&cad= rja\&uact=8\&ved=0ahUKEwjm7prU0qrPAhXDo48KHaEqAfUQFggzMAI\&url $=$ http $\% 3 \mathrm{~A} \% 2 \mathrm{~F} \% 2 \mathrm{Fejournal}$. stainpamekasan.ac.id\%2Findex.php $\% 2 \mathrm{Ftadris} \% 2 \mathrm{Fa}$ 
rticle\%2Fview\%2F247\%2F238\&usg=AFQjCNF0H7cgobqQFllCOgcCmboeufG hJQ\&sig2=J--kIwVU--31vZNnB6sFiA

Mutawah, M. A. A. (2015, October). The influence of mathematics anxiety in middle and high school students math achievement. International Educational Studies. 8(11). 239-252. Retrieved from http://files.eric.ed.gov/fulltext/EJ1082131.pdf

Omrod, J. E. (2008). Psikologi pendidikan: Membantu siswa tumbuh dan berkembang. Jakarta: Erlangga.

Peraturan Menteri Pendidikan Nasional. (2006). Lampiran peraturan Menteri Pendidikan Nasional nomor 22 tahun 2006 tanggal 23 Mei 2005. Diunduh dari http://dokumen.tips/documents/permendiknas-no-22-tahun-2006-standarisi.html

Purwanto. (2009). Evaluasi hasil belajar. Yogyakarta: Pustaka Pelajar.

Rounds, J. \& Hendel, D. (1980). Measurement and dimensionality of mathematics anxiety. Journal of Counseling Psychology, 27, 138-149.

Seng, E. L. K. (2015, October). The influence of pre-university students's mathematics test anxiety and numerical anxiety on mathematics achievements. International Education Studies, 8 (11). Doi 10.5539/ies.v8n11p162

Solikah, M. (2012). Pengaruh kecemasan siswa pada matematika dan motivasi belajar terhadap prestasi belajar matematika. eJournal UNNESA. 1(1). 1-8. Diunduh dari http://ejournal.unesa.ac.id./index.php/mathedunesa/article/view/251/406

Sugiyono. (2011). Metode penelitian kuantitatif, kualitatif, dan R\&D. Bandung: Alfabeta.

Suinn, R. M. \& Winston, E. H. (2003). The mathematics anxiety reting scale, a brief version: psychometric data. Psychological Reports, 92, 167-173.

Suriasumantri, J. S. (2009). Filsafat ilmu: Sebuah pengantar populer. Jakarta: Pustaka Sinar Harapan.

Syah, M. (2007). Psikologi belajar. Jakarta: Raja Grafindo.

Wicaksono, A. B. \& Saufi, M. (2013, November). Mengelola kecemasan siswa dalam pembelajaran matematika. Prosiding. Diunduh dari http://eprints.uny.ac.id/10735/1/P\%20-\%2012.pdf

Zakaria, E. \& Nordin, N. M. (2008). The effects of mathematics anxiety on matriculation students as related to motivation and achievement. Eurasia Journal of Mathematics, Science \& Technology Education. 4(1), 27-30. Diunduh dari http://www.ejmste.com/v4n1/Eurasia_v4n1_Zakaria_Nordin.pdf 